\title{
Management Innovation for Thai Language and Culture Program of International Schools in Thailand Based on Concept of Agile Learner Characteristics
}

\author{
Charuwan Byrum ${ }^{1}$, Chayapim Usaho ${ }^{1}, \&$ Pruet Siribanpitak ${ }^{1}$ \\ ${ }^{1}$ Department of Educational Policy, Management and Leadership, Faculty of Education, Chulalongkorn \\ University, Bangkok, Thailand \\ Correspondence: Chayapim Usaho, Department of Educational Policy, Management and Leadership, Faculty of \\ Education, Chulalongkorn University, Bangkok, Thailand. Tel: 668-1802-3232. E-mail: phynixs@ hotmail.com
}

Received: January 25, 2021

Accepted: March 6, $2021 \quad$ Online Published: March 31, 2021

doi:10.5539/ass.v17n4p10

URL: https://doi.org/10.5539/ass.v17n4p10

\begin{abstract}
The research aimed to develop an innovation for the Thai language and culture program management based on the concept of agile learner characteristics in Thailand. The study used the multiphase mixed-method approach which was conducted among 97 international schools in Thailand.

The research findings revealed that management innovation for Thai language and culture program of international schools in Thailand based on the concept of agile learner characteristics which was titled "SWABK". It consisted of three main components that promoting agile learner characteristics of seeking challenging situations, being a cognitive thinker, knowing what to do when facing uncertain situations, and welcoming feedback and criticism : (1) curriculum development: identifying learning outcomes that align with the need of Thai and global society and designing learning units by integrating Thai language and culture into global situations, (2) instruction: constructing learning tools and materials to be accessible anytime and anywhere, and (3) evaluation: utilizing the curriculum evaluation's result to further develop learners to be ready for the future.
\end{abstract}

Keywords: International Schools in Thailand, Thai Language and Culture Program Management, Agile Learner Characteristics, Management Innovation

\section{Introduction}

\subsection{Thai Language and Culture Program for International Schools in Thailand}

The rise of the number of Thai national students attending international schools in Thailand has ignited the question on the effectiveness of the Thai language and culture program has to offer the nation's future leaders. According to the International Schools Association of Thailand, there were 52,000 students in the academic year 2016 growing from 29,747 students in the academic year 2009 (Somboon, 2017). As claimed in Bangkok Patana School's website, the school has a diverse student population of over 65 nationalities with $20 \%$ Thai nationality (B. P. School, 2020). While ISB, International School Bangkok claims $22 \%$ of Thai national students among 60 countries in the school year of 2016-17 (Bangkok, 2016). NIST has approximately 25.3\% of Thai national students among 60 nationalities (N. I. School, 2020). Thai students in international schools are from well economic status indicated by the range of tuition fee starting from 250,000 to one million baht per year (Admin, 2019). These students will most likely become future leaders in social, economic, and political sectors.

It is undeniable that we are living in a world of rapid change. Technology has become a main part of our lives that provides us with conveniences in many ways, but it can become a major threat to us as evidenced by the rise of Artificial Intelligence. The academic contents that schools teach students today might not be useful for them to use at work or to live life within the future. The vision of the Thai language and culture program for international schools documented by the Office of the Private Education Commission (OPEC) states that the subject of Thai language, culture and history is aimed to develop student's skills to communicate in Thai at their fullest potential. Thai national students are the vital manpower to the nation's future, they are to be good, capable , and happy citizens living lives according to Thai tradition and culture, and adhering to the democracy of the constitutional monarchy (OPEC, 2016). This clearly shows that communication is one of the top leadership 
skills that leaders should have. A leader must be an effective communicator at all forms (Doyle, 2019). Hattori states that a leader must satisfy three needs of others; communication, connection, and understanding (Hattori, 2015) (p. 63).

Mr. Schleicher, the OECD Director for Education and Skills states that schools can equip students with knowledge, skills, attitudes and values they need to thrive and shape their world (Howells, 2018). In Britain, APPG or All-Party Parliamentary Group for Education held a meeting in May 2017 to discuss "How Well do Schools Prepare Children for their Future?" They see the importance of young people today to be equipped with skills that allow them to be adaptable to changing circumstances. Though basic literacy and numeracy skills are still essential for their success in employment, soft skills, character and resilience are vital skills that are lacking in young people claimed by most employers (Kinahan, 2017). The Mitchell Institute for Education and Health Policy at Victoria University, Australia identifies four possible solutions that education can prepare students to be ready in the future. One of them is to enhance student's capabilities of both streams which are academic knowledge, and the mindsets or characteristics needed to navigate a changing society and economy (Torii \& O'Connell, 2017).

What schools need to do to craft future leaders in supporting Thailand's Vision 2037 that indicates Thailand to become "a developed country with security, prosperity and sustainability in accordance with the Sufficiency Economy Philosophy" (Board, 2018). Thailand Education National Plan has adopted the National Strategy indicating that Thai citizens in 2037 are to have the capability to develop the country collaboratively, enable to adapt to the context of future development, be mentally and physically prepared and equipped with analytical and life-long learning skills, be immune to change, be culturally conscious mind and Thai identity, be responsible, be a solid foundation to community, society, and love the country and the monarchy (Education, 2017). Therefore, international schools in Thailand which house these future leaders of the nation bear an important role to provide students with the knowledge and skills needed in the future. These Thai students are surrounded by the international environment, they are and will be growing up in the future of internationality. Therefore, it is vital that the school's Thai language and culture program needs to prepare students to be ready to encounter and handle any future rapid changes in order to live life successfully in both international and Thai contexts.

Teaching and learning Thai in international schools have been a challenge to both teachers and students due to multi-proficiency levels in each class. Most international schools use English as the medium of instruction. The Ministry of Education (MoE, 2007) requires all international schools in Thailand to provide and teach the Thai language and culture class to Thai national students one period of 50 minutes a day and the minimum of five days per week. Thai national students have opportunities to expose to structured Thai literacy for only about $12 \%$ of their day, let alone schools that are unable to comply with this requirement. As the result, the majority of Thai national students in international schools show limited abilities in their reading and writing skills. The Thai curriculum used in international schools proves the proclaimed statement. The Thai language, culture and history curriculum revised in 2015 by the Office of the Private Education Commission indicates lower learning expectations compared to the National Thai curriculum used in Thai schools. This could lead to the difficulty in reaching the objectives of the Thai language and culture program mentioned previously.

Many international schools design their own curriculum and self-create the learning materials and textbooks to best serve their student's Thai proficiency. The nature of the student body in Thai classes in international schools is the combination of multi proficiency levels. There are students who begin their early year in international schools, they find learning Thai is too hard, and become demotivated to learn Thai. Also, students who later on decide to transfer from Thai to international schools, they find Thai class is too easy and not challenging enough to keep them engaged. They gradually lose their Thai skills due to being inactive during class. This poses a challenge on instructions and a threat to Thailand's future leaders. Having low Thai language skills and Thai cultural understanding mean that Thai students in international schools are lacking one of the most important skills that leaders must have which is the communication.

\subsection{Agile Leaner Characteristics}

In search of preparation for Thai national students in international schools to be ready for a changing world and to motivate them to fully engage in learning Thai have led the focus towards the concept of agile learner characteristics. What is an agile learner? How might it solve mentioned problems? The Cambridge Dictionary defines agile as being able to think quickly and clearly. The Oxford Dictionary defines agile as being able to think and understand quickly. According to Spurgin, agile learners are ready for change and new learning, they are able to use what they know with new knowledge in new situations (Spurgin, 2016). As quoted in Galagan's 
article, Korn Ferry which is a leading global leadership, people and organizational advisory firm define "highly agile leaners as those who learn from past experiences and then apply what they learned to new situations, continually acquire new skills. Face new challenges, and perform well under changing conditions and ambiguity" (Galagan, 2015). Agile learners are proactive and always on the lookout to learn. They are engaged and inspired by the learning process. Their interpersonal skill is high and being used effectively. When coming across with any difficulties or problems, agile learners are not afraid to speak up or speak to as many people to gather as much information needed to accumulate all possibilities to solve the problem. They are comfortable being out of their comfort zone and enjoy being in the learning zone where in which sustains their success in the world of rapid changes. As cited in Valcour's article (Valcour, 2015), David Peterson, director of executive coaching and leadership at Google says, "Staying within your comfort zone is a good way to prepare for today, but it's a terrible way to prepare for tomorrow". Agile learners understand that they are capable of changing themselves, behaving intelligently, engaging more effectively in virtuous practice, and successfully addressing difficult problems (Anderson, 2017).

The Thai language and culture program management that emphasizes on instilling agile learner characteristics in today's students would enhance the level of motivation in learning Thai and also prepare students to become quality Thai citizen who live lives successfully in global and Thai context.

\subsection{Research Questions}

1. What are the conceptual frameworks of the Thai Language and Culture Program Management for International Schools in Thailand and the Agile Learner Characteristics?

2. What are the needs to develop the management innovation for the Thai Language and Culture Program Management for International Schools in Thailand based on the concept of agile learner characteristics?

3. What does the management innovation for the Thai Language and Culture Program Management for International Schools in Thailand based on the concept of agile learner characteristics look like?

\section{Research Methodology}

1. The research used a multiphase mixed method design of quantitative and qualitative analysis comprised of three stages.

2. Research process comprises of three stages.

Table 1. Research Process

\begin{tabular}{|c|c|c|c|c|c|}
\hline Objectives & Process & $\begin{array}{c}\text { Participant / } \\
\text { Sampling / } \\
\text { Population }\end{array}$ & Instruments & Data Analysis & Result \\
\hline $\begin{array}{l}\text { 1. To study } \\
\text { conceptual } \\
\text { framework of } \\
\text { Thai language \& } \\
\text { culture program } \\
\text { management for } \\
\text { international } \\
\text { schools in } \\
\text { Thailand, \& agile } \\
\text { learner } \\
\text { characteristics }\end{array}$ & 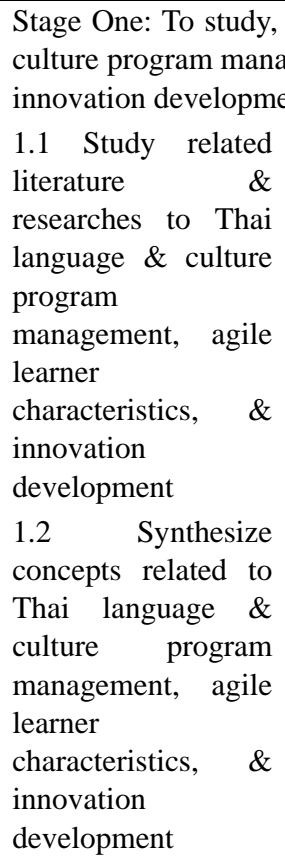 & $\begin{array}{l}\text { ynthesize, and eval } \\
\text { gement for internatic } \\
\text { nt } \\
\text { Related literature } \\
\& \text { researches to } \\
\text { Thai language \& } \\
\text { culture program } \\
\text { management, } \\
\text { agile learner } \\
\text { characteristics, \& } \\
\text { innovation } \\
\text { development }\end{array}$ & $\begin{array}{l}\text { ate the conceptu } \\
\text { tal schools in Th } \\
\text { Synthesis table }\end{array}$ & $\begin{array}{l}\text { framework of th } \\
\text { and, agile learne } \\
\text { Content } \\
\text { Analysis } \\
\text { Frequency }\end{array}$ & $\begin{array}{l}\text { Thai language and } \\
\text { haracteristics, and } \\
\text { Draft of the } \\
\text { conceptual } \\
\text { framework for } \\
\text { the Thai } \\
\text { language \& } \\
\text { culture program } \\
\text { management } \\
\text { Draft of the } \\
\text { conceptual } \\
\text { framework for } \\
\text { agile learner } \\
\text { characteristics }\end{array}$ \\
\hline
\end{tabular}


2. To study the needs to develop the Thai language \& culture program management based on the concept of agile learner characteristics

$\begin{array}{llll}\begin{array}{l}1.3 \quad \text { Evaluate } \\ \text { conceptual } \\ \text { framework for this } \\ \text { study }\end{array} & \begin{array}{l}\text { Five specialists in } \\ \text { the areas of } \\ \text { educational } \\ \text { management, } \\ \text { agile learner } \\ \text { characteristics, } \\ \text { innovation } \\ \text { development }\end{array} & \begin{array}{l}\text { Frequency } \\ \text { framework } \\ \text { evaluation form }\end{array} & \begin{array}{l}\text { Revised } \\ \text { conceptual } \\ \text { framework for }\end{array} \\ & & \begin{array}{l}\text { Thai language \& } \\ \text { culture } \\ \text { management, }\end{array} \\ & & \begin{array}{l}\text { agile learner } \\ \text { characteristics \& } \\ \text { innovation } \\ \text { development }\end{array}\end{array}$

Stage Two: Preliminary study the current and the desirable states, and analyze needs to develop the Thai language \& culture program management based on the concept of agile learner characteristics (The process of management innovation development, Phase 1: Define needs for innovation)

2 2.1 Draft the Revised questionnaire conceptual framework for Questionnaire Structure

Content Thai language \& culture management, agile learner characteristics, and innovation development analysis 2.2 Evaluate validity
of the questionnaire

5 professionals in the areas of evaluation form educational management, agile learner, \& research

2.3 Try out the Administrators \& Thai teachers of international questionnaire for its reliability

schools that are not the sample group The questionnaires

Validity

Analysis with the IOC more that 0.70
IOC Analysis 
3. To develop the management innovation for the Thai language \& culture program of international schools in Thailand based on the concept of agile learner characteristics

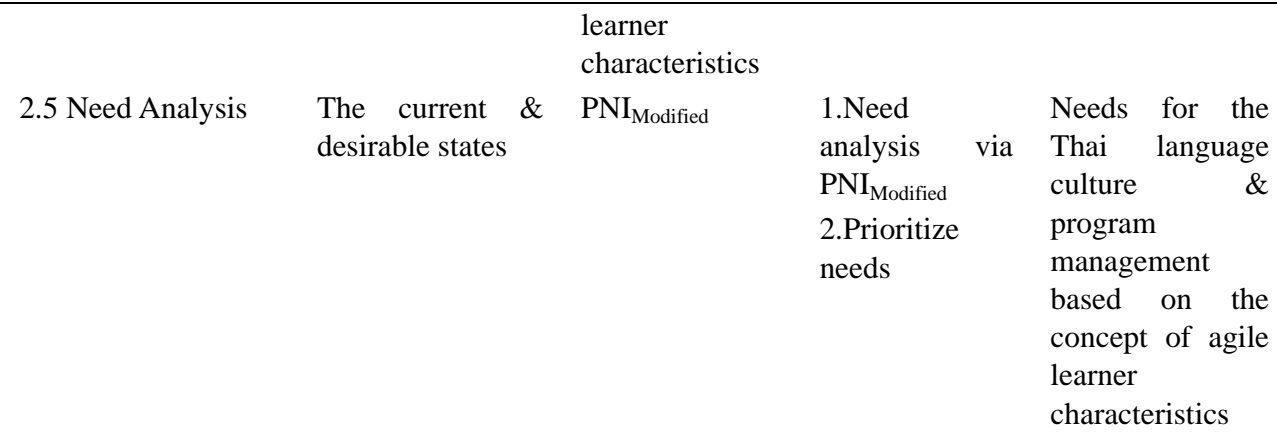

Stage Three: Develop management innovation for the Thai language \& culture program management based on the concept of agile learner characteristics

(The process of management innovation development, Phase 2: Discover ideas to formulate innovation, Phase 3: Develop innovation, and Phase 4: Demonstrate feasibility)

\subsection{Draft the \\ management \\ Synthesis table \\ Content analysis}

innovation for the

Thai language \&

culture program

based on the

concept of agile

learner

characteristics

1.Literature \&
researches of best
practices related
to the program
and the concept
of agile learner
characteristics
2.The analysis
result of the
current $\&$
desirable states,
and needs

3.2Develop

management

innovation for the

Thai language \&

culture program

management based

on the concept of

agile learner

characteristics

of

(The process of

management

innovation, Phase 3:

Develop innovation)

$\begin{aligned} & 3.3 \quad \text { Evaluate } \\ & \text { feasibility of the }\end{aligned}$ or $\begin{array}{r}\text { Stakeholders } \\ \text { innovation }\end{array}$ by users
individuals (The
process of
management
innovation
development, Phase
4: Demonstrate
feasibility)

9 Experts \& stakeholders in the areas of Thai language \& culture program management, agile learners, \& innovation development

$1^{\text {st }}$ Draft of the management innovation for the Thai language \& culture program for international schools in Thailand based on the concept of agile learner characteristic

$1.2^{\text {nd }}$ Draft of 1.Mean the Standard management deviation innovation for analysis the Thai 2.Content language \& analysis culture program of international schools in Thailand based on the concept of agile learner characteristics

2.The form to evaluate feasibility of the management $1^{\text {st }}$ draft of the management innovation for the Thai language \& culture program of international schools in Thailand based on the concept of agile learner characteristics $2^{\text {nd }}$ Draft of the management innovation for the Thai language \& culture program for international schools in Thailand based on the concept of agile learner characteristics

\& 1 .The feasibility analysis result for the $2^{\text {nd }}$ Draft of the management innovation for the Thai language \& culture program of international schools in Thailand based on the concept of agile learner characteristics 2 . Completed draft of the management innovation for 


\section{Results}

The analysis result is presented in narrative along with tables describing frequency distribution, percentage, means, standard deviation (S.D.) and PNImodified index. The content analysis was used on the qualitative study. The results of data analysis are presented as follows.

3.1 The conceptual framework for the Thai language and culture program management, agile learner characteristics, and innovation development

THAI LANGUAGE \& CULTURE PROGRRAM

MANAGEMENT OF INTERNATIONAL

\section{SCHOOLS IN THAILAND}

Synthesized from (WASC, 2016), (NEASC), (CIS), (EDT),

$$
\text { (OPEC, 2016) }
$$

1. Curriculum Development

1.1. Identify learning outcomes

1.2. Identify learning standard

1.3. Develop learning units

2. Instruction

2.1. Identify learning objectives

2.2. Construct learning activities

2.3. Construct learning tools

2.4. Identify assessment evidences

3. Evaluation

3.1. Examine learner's quality

3.2. Examine curriculum

3.3. Examine instruction

3.4. Utilize the curriculum evaluation's result to further develop learners to be ready for the future

\section{AGILE LEARNER CHARACTERISTICS}

Synthesized from (Lombardo \& Eichinger, 2000), (De

Meuse, Dai, \& Hallenbeck, 2010), (Hallenbeck, Swisher, \& Orr, 2011), (Mitchinson \& Morris, 2012)), (Lewis, Orr, \&

Buxton, 2014), (Burke, Roloff, \& Mitchinson, 2016),

(Anderson, 2017)

1. Characteristics in cognitive domain

1.1. Being goal-oriented

1.2. Being a cognitive thinker

2. Characteristics in affective domain

2.1. Being eager and curious to learn new ideas

2.2. Welcoming feedback and criticism

3. Characteristics in psychomotor domain

3.1. Seeking challenging situations

3.2. Knowing what to do when facing uncertain situations

3.3. Reacting promptly to change and ineffective strategies

3.4. Having highly effective interpersonal skills

INNOVATION DEVELOPMENT

Synthesized from (O'Sullivan \& Dooley, 2009), (Ng, 2014), (GROUP), \&

(Hengsberger, 2018)

1. Define need for innovation

2. Discover ideas to formulate innovation

3. Develop innovation

4. Demonstrate feasibility

\section{Management Innovation for the Thai Language and Culture Program}

of International Schools in Thailand Based on the Concept of Agile Learner Characteristics

Figure 1. The completed conceptual framework 
3.2 Current and desirable states, and need analysis to develop management innovation for the Thai language and culture program management based on the concept of agile learner characteristics (The process of management innovation development, Phase 1: Define needs for innovation)

Table 2. Overall current and desirable states, and need prioritization

\begin{tabular}{|c|c|c|c|c|c|c|c|c|c|c|}
\hline \multirow[b]{2}{*}{ Thai Language and Culture Program Management } & \multicolumn{5}{|c|}{ Current state } & \multicolumn{3}{|c|}{ Desirable state } & \multicolumn{2}{|c|}{ Need } \\
\hline & $X$ & S.D. & $\begin{array}{l}5 \\
\substack{0 \\
0 \\
0}\end{array}$ & $\begin{array}{l}\stackrel{0}{0} \\
\stackrel{\oplus}{\oplus}\end{array}$ & $X$ & S.D. & $\begin{array}{l}5 \\
0 \\
0 \\
\mathbb{2}\end{array}$ & $\begin{array}{l}\text { ○ } \\
\stackrel{\leftrightarrow}{ه}\end{array}$ & 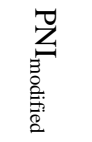 & \\
\hline 1.Curriculum Development & 3.61 & 0.77 & high & 3 & 4.51 & 0.65 & highest & 2 & 0.249 & 1 \\
\hline 2.Instruction & 3.64 & 0.73 & high & 2 & 4.53 & 0.67 & highest & 1 & 0.245 & 2 \\
\hline 3.Evaluation & 3.65 & 0.77 & high & 1 & 4.49 & 0.70 & high & 3 & 0.230 & 3 \\
\hline TOTAL & 3.63 & 0.76 & high & & 4.51 & 0.67 & highest & & & \\
\hline
\end{tabular}

The Table 2 shows the overall current state of the Thai language and culture program management according to the concept of agile learner characteristics at the high level $(x=3.63$, S.D. $=0.76)$. Considering each factor finds that the evaluation has the highest average score at the high level $(\mathrm{x}=3.65$, S.D. $=0.77)$, following with the instruction at the high level $(\mathrm{x}=3.64$, S.D. $=0.73)$, and the curriculum development with the lowest average score at the high level $(\mathrm{x}=3.61$, S.D. $=0.77)$. The element of evaluation shows that examining learner's quality according to indicated learning outcomes has the highest average score at the high level $(X=3.69$, S.D. $=0.74)$. The characteristics in the cognitive domain show the highest average score at the high level $(X=3.73$, S.D. $=$ 0.70), following with the characteristics in the cognitive and the psychomotor domain at the same high level (X $=3.69$, S.D. $=0.75$ ). The element of instruction shows that identifying learning objectives aligning with learning outcomes has the highest average score at the high level $(X=3.71$, S.D. $=0.72)$. The characteristics in affective domain show the highest average score at the high level $(X=3.75$, S.D. $=0.72)$, following with the characteristics in the cognitive domain at the high level $(X=3.74$, S.D. $=0.72)$, and the characteristics in the psychomotor domain at the high level $(X=3.67$, S.D. $=0.74)$. The element of curriculum development shows that designing learning units by integrating Thai language and culture into global situation has the highest average score at the high level $(X=3.62$, S.D. $=0.78)$.

The overall desired state of the Thai language and culture program management according to the concept of agile learner characteristics is at the highest level $(\mathrm{x}=4.51$, S.D. $=0.67)$. Considering each factor finds that the instruction has the highest average score of the desired state at the highest level $(\mathrm{x}=4.53$, S.D. $=0.67)$, following with the curriculum development at the highest level $(\mathrm{x}=3.51$, S.D. $=0.65)$, and the evaluation with the lowest average score at the high level $(\mathrm{x}=4.49$, S.D. $=0.70)$. The element of instruction shows that identifying learning objectives aligning with learning outcomes has the highest average score at the highest level $(\mathrm{X}=4.59$, S.D. $=$ 0.59). The characteristics in the cognitive domain show the highest average score at the highest level $(X=4.61$, S.D. $=0.58)$, following with the characteristics in the affective domain at the highest level $(X=4.60$, S.D. $=$ $0.58)$, and the characteristics in the psychomotor domain at the highest level $(X=4.57$, S.D. $=0.59)$. The element of curriculum development shows that designing learning units by integrating Thai language and culture into global situation has the highest average score at the highest level $(X=4.52$, S.D. $=0.66)$. The characteristics in cognitive domain show the highest average score at the high level $(X=4.54$, S.D. $=0.67)$, following with the characteristics in psychomotor domain at the high level $(X=4.52$, S.D. $=0.65)$, and the characteristics in the affective domain at the high level $(X=4.51, S . D .=0.67)$. The element of evaluation shows that examining learner's quality according to indicated learning outcomes has the highest average score at the highest level $(\mathrm{X}=$ 4.52 , S.D. $=0.67)$. The characteristics in the affective domain show the highest average score at the highest level $(X=4.57$, S.D. $=0.59)$, following with the characteristics in the psychomotor domain at the highest level $(X=$ 4.53, S.D. $=0.68)$ ], and the characteristics in the cognitive domain at the high level $(X=4.46$, S.D. $=0.71)$.

The need analysis indicates that the curriculum development is needed to be further developed with the highest PNImodified $=0.249$. The second highest is the instruction with the PNImodified $=0.245$, and the evaluation comes in last with the PNImodified $=0.230$. In the element of curriculum development shows that identifying learning outcomes aligning with the need of Thai and global society of characteristics in psychomotor domain is needed to be further developed with the highest PNImodified $=0.249$. Furthermore, designing learning units by integrating Thai language and culture into global situation of characteristics in cognitive domain is also needed 
to be further developed with the same highest PNImodified $=0.249$. Identifying learning standard basing on proficiency shows the lowest PNImodified $=0.247$. In the element of instruction shows that constructing learning tools and materials to be accessible anytime and anywhere with the characteristics in the cognitive and the affective domains are needed to be further developed with the same highest PNImodified $=0.265$. The characteristics in the psychomotor domain shows the lowest PNImodified $=0.258$. In the element of evaluation shows the highest PNImodified $=0.242$ on utilizing the curriculum evaluation's result to further develop learners to be ready for the future with the characteristics in the cognitive domain (PNImodified $=0.253$ ) that is needed to be further developed.

3.3 Management innovation for the Thai language and culture program of international schools in Thailand based on the concept of agile learner characteristics (The process of management innovation development, Phase 2: Discover ideas to formulate innovation, Phase 3: Develop innovation, and Phase 4: Demonstrate feasibility)

This research is conducted under the process of management innovation development phase 1 which is to define needs for innovation by studying current and desirable states of the Thai language and culture program management based on the concept of agile learner characteristics. Then the need analysis is conducted to define needs which are brought into phase 2 to discover ideas to formulate innovation. Literature reviews, content analysis of feedbacks from open-ended questions, and best practices are studied and later to formulate the first draft of the innovation. The focus- group of nine experts and stakeholders is conducted to obtain suggestions and to move along to phase 3 which is to develop innovation. The first draft of innovation is adjusted according to the expert and stakeholder's inputs and resulted in the second draft of innovation. The second draft of the innovation is to evaluate its suitability and possibility by 15 stakeholders or innovation users individually.

Table 3. Analysis and synthesis to formulate innovation for the Thai language and culture program management based on the concept of agile learner characteristics

\begin{tabular}{|c|c|c|}
\hline $\begin{array}{c}\text { Innovation } \\
\text { Development }\end{array}$ & $\begin{array}{l}\text { Define Needs } \\
\text { (Phase 1) }\end{array}$ & $\begin{array}{l}\text { Discover new ideas to formulate innovation } \\
\text { (Phase 2) }\end{array}$ \\
\hline $\begin{array}{l}\text { Curriculum } \\
\text { Development }\end{array}$ & $\begin{array}{l}\text { From the analysis of current and desirable } \\
\text { states of Thai language and culture program for } \\
\text { international schools in Thailand based on the } \\
\text { concept of agile learner characteristics found } \\
\text { the highest need in curriculum development as } \\
\text { follows. } \\
\text { Identifying learning outcomes that align with } \\
\text { the need of Thai and global society which } \\
\text { promotes the characteristics of seeking } \\
\text { challenging situation and knowing what to do } \\
\text { when facing uncertain situations. } \\
\text { Designing learning units by integrating Thai } \\
\text { language and culture into global situations and } \\
\text { promoting the characteristic of seeking } \\
\text { challenging situation, being a cognitive thinker } \\
\text { and knowing what to do when facing uncertain } \\
\text { situations. }\end{array}$ & $\begin{array}{l}\text { Literature and researches of best practices in the } \\
\text { area of new way for curriculum development had } \\
\text { been conducted and found the following. } \\
\text { Project-based curriculum is a student-centered } \\
\text { pedagogy that students acquire a deeper } \\
\text { knowledge through active exploration of } \\
\text { real-world challenges and problems. } \\
\text { Curriculum is interdisciplinary. Thai subject is } \\
\text { integrated to global context. } \\
\text { Curriculum promotes characteristics of seeking } \\
\text { challenging situations, being a cognitive thinker } \\
\text { and knowing what to do when facing uncertain } \\
\text { situations. } \\
\text { Curriculum promotes problem finding to enhance } \\
\text { intellectual and imaginative vision. }\end{array}$ \\
\hline Instruction & $\begin{array}{l}\text { From the analysis of current and desirable } \\
\text { states of Thai language and culture program for } \\
\text { international schools in Thailand based on the } \\
\text { concept of agile learner characteristics found } \\
\text { the highest need in instruction as followed. } \\
\text { Constructing learning tools and materials to be } \\
\text { accessible anytime and anywhere with the } \\
\text { characteristics of seeking challenging } \\
\text { situation, being a cognitive thinker and } \\
\text { knowing what to do when facing uncertain } \\
\text { situations. }\end{array}$ & $\begin{array}{l}\text { Literature and researches of best practices in the } \\
\text { area of new way for instruction had been } \\
\text { conducted and found the following. } \\
\text { 1.Learners have opportunities to interact with } \\
\text { what they are learning or content, with peers or } \\
\text { classmates, with teacher, and with community to } \\
\text { practice cognitive thinking skills, collaborative } \\
\text { skills, and taking or giving criticisms via } \\
\text { project-based learning. } \\
\text { 2.Learning is personalized to meet individual } \\
\text { interests and needs. Instruction is designed to } \\
\text { support learner's voice and choice. } \\
\text { 3. Technology enables personalized pathways for } \\
\text { student learning through active and collaborative }\end{array}$ \\
\hline
\end{tabular}


Evaluation
From the analysis of current and desirable states of Thai language and culture program for international schools in Thailand based on the concept of agile learner characteristics found the highest need in instruction as followed.

Utilizing the curriculum evaluation's result to further develop learner to be ready for the future with characteristics of seeking challenging situation, being a cognitive thinker and knowing what to do when facing uncertain situations. learning activities. Technology offers anywhere, anytime learning opportunities. Technology provides pathway for learner's interaction with content, peers, teachers, and community.

Literature and researches of best practices in the area of new way for curriculum evaluation had been conducted and found the following.

1.Build in future ready skill outcomes in formative and summative assessments and encourage more performance-based or contributing assessments.

2. Assessment is data-driven decision making that impacts, informs, and improves learning in real time.

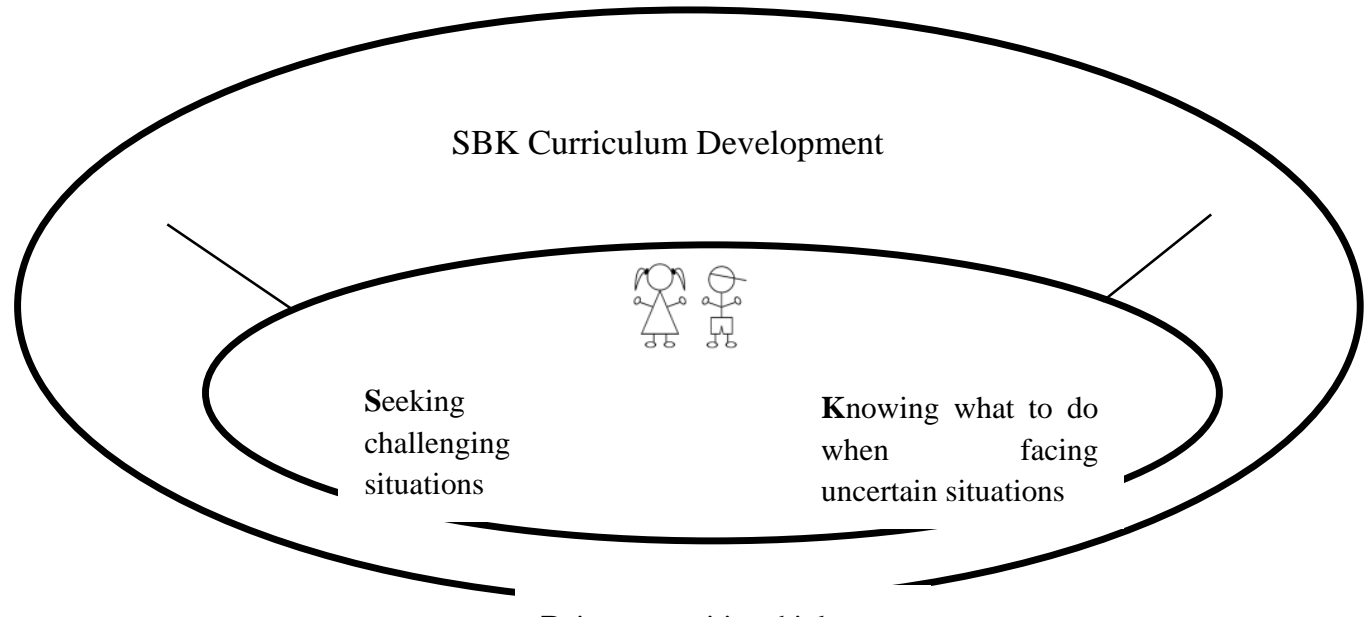

Being a cognitive thinker<smiles>[Mg][Mg][Mg]</smiles><smiles>CCI</smiles><smiles></smiles>

Figure 2. The $1^{\text {st }}$ draft of the Management Innovation for the Thai Language and Culture Program of International Schools in Thailand based on the Concept of Agile Learner Characteristics with SBK Innovation

SBK Innovation is the Thai Language and Culture Program Management that promotes the student's characteristics of seeking challenging situations, being a cognitive thinker, and knowing what to do when facing uncertain situations. SBK Innovation composes of SBK Curriculum Development, SBK Instruction, and SBK Evaluation.

In the essence of SBK Curriculum Development is that the curriculum is current to local and global issues, combined Thai and other subjects together, challenging to enhance intellectual, collaboratively oriented, and content creation oriented. The practices are to identify learning outcomes that align with the need of Thai and global society which promotes the characteristics of seeking challenging situations, being a cognitive thinker, and knowing what to do when facing uncertain situations, and to design learning units by integrating Thai language and culture into global situations and promoting the characteristics of seeking challenging situations, being a cognitive thinker, and knowing what to do when facing uncertain situations.

In the essence of SBK Instruction is that the instruction provides opportunities for students to interact with peers, content, community, and teacher, and engage in learning activities before, during, and after the face to face class or 24/7 through Scrum framework. The practice is to constructing learning tools and materials to be accessible 
anytime and anywhere with the characteristics of seeking challenging situation, being a cognitive thinker, and knowing what to do when facing uncertain situations.

In the essence of SBK Evaluation is that the evaluation inspects future-ready pathways for students. The practice is to utilize the curriculum evaluation's result to further develop learners to be ready for the future with characteristics of seeking challenging situations, being a cognitive thinker, and knowing what to do when facing uncertain situations.

Table 4. Demographic data of the experts and stakeholders evaluating innovation's feasibility and suitability

\begin{tabular}{cccc}
\hline \multirow{2}{*}{ Group } & Demographic Information & \multicolumn{2}{c}{ Total } \\
\cline { 2 - 4 } & Expert in the areas of innovation and management innovation & Quantity & Percentage \\
\hline 1 & Expert in the area of agile learner characteristics & 2 & 22.22 \\
3 & Thai Headmaster /. Headmistress & 2 & 22.22 \\
4 & Thai teacher from grade 1-12 & 2 & 22.22 \\
& TOTAL & 3 & 33.34 \\
\end{tabular}

Table 5. Evaluation of the $1^{\text {st }}$ draft of the innovation

\begin{tabular}{cccc}
\hline \multirow{2}{*}{ Question } & Description & Number of People \\
\cline { 2 - 4 } & Angree & Disagree \\
\hline 1 & Principle and rationale of the innovation & 6 & 3 \\
3 & Objective of the innovation & 9 & 0 \\
4 & Result of the innovation & 9 & 0 \\
5 & Innovation features & 7 & 2 \\
6 & Structure and infographic of innovation & 8 & 1 \\
7 & Essence, practice, and benchmark & 5 & 4 \\
8 & Implementation & 7 & 2 \\
\hline
\end{tabular}

The result presented in Table 5 revealed that the majority of the experts and stakeholders agreed with the feasibility and suitability of the $1^{\text {st }}$ draft of the innovation. Additional comments were recorded for further adjustment and resulted in the $2^{\text {nd }}$ draft of the innovation titled "SWABK". The characteristic in the affective domain of welcoming feedback and criticism with the highest PNImodified was added so that characteristics from all three learning domains were covered. There was the rearrangement of each characteristic's abbreviation in order to make the innovation title easy to call and remember. " $A$ " standing for agile learner has been added so that the innovation title can be pronounced as a word. SWABK aims to develop three elements which are the curriculum development, the instruction, and the evaluation that enable international schools to develop its management that leads to promoting the future-ready characteristics among students as follows.

$\mathrm{S}=$ Seeking challenging situations: Students are courageous to stepping out of their comfort zone to explore and try new experiences which lead to constantly new learning.

$\mathrm{W}=$ Welcoming feedback and criticism: Students practice giving constructive criticism and critically listen to other's criticism to refine their work, their ways of learning and practices to achieve their set goals.

A= Agile Learner

$\mathrm{B}=$ Being a cognitive thinker: Students are able to think critically, connect and apply what they have already known to new knowledge to benefit their current work.

$\mathrm{K}=$ Knowing what to do when facing uncertain situations: Students calmly figure out ways to overcome hurdles and obstacles to finally accomplish their goals. 


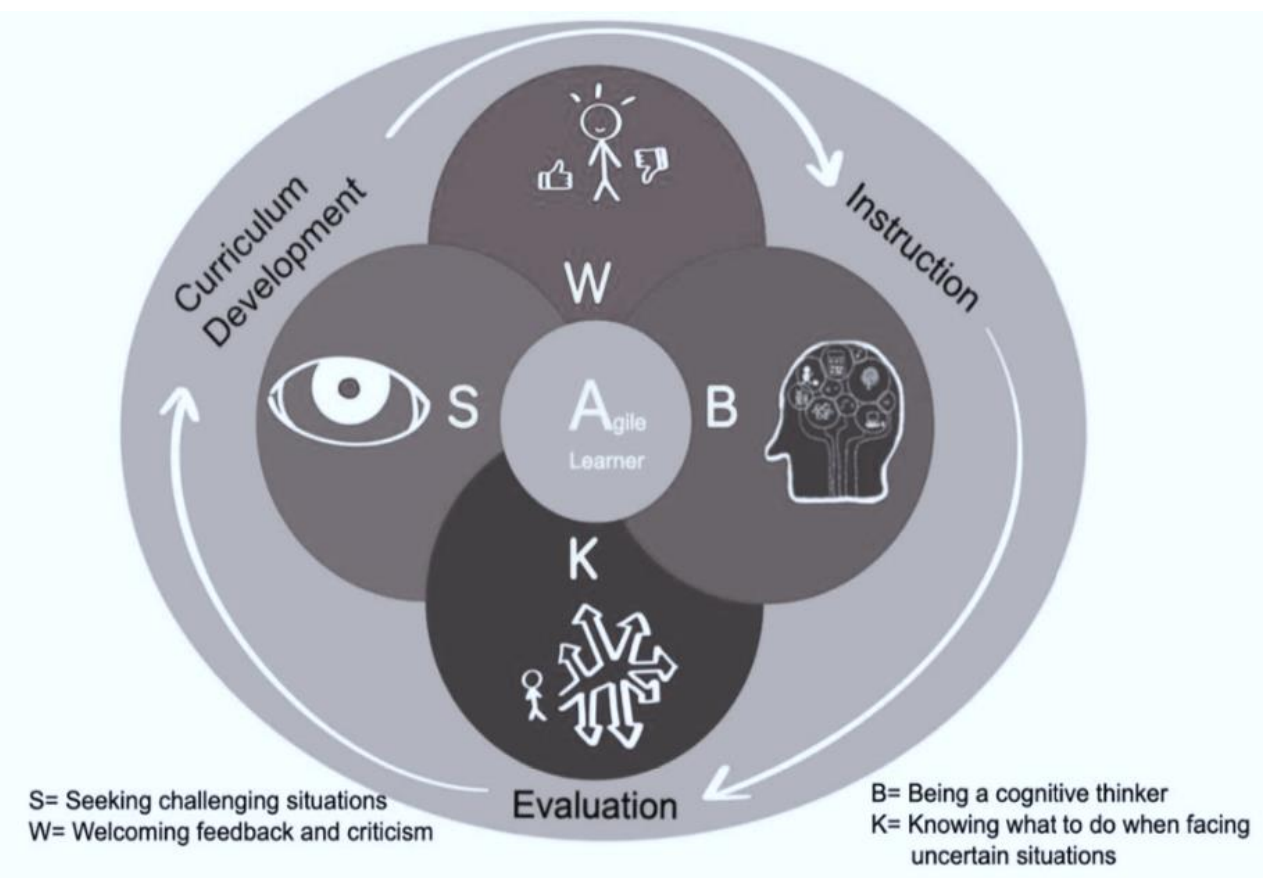

Figure 3. Structure and Infographic of Innovation "SWABK"

\section{Discussion}

"SWABK" the management innovation of the Thai language and culture program developed from this research study is suitable to promote expected characteristics: seeking challenging situations, being a cognitive thinker, welcoming feedback and criticism, and knowing what to do when facing uncertain situations.

4.1 The curriculum development with SWABK innovation would craft a curriculum that is flexible and adjustable to change, current to local and global society, relevant to students, interdisciplinary, collaborative, and promoting the expected characteristics: seeking challenging situations, welcoming feedback and criticism, being a cognitive thinker, and knowing what to do when facing uncertain situations. Schools must transform curriculum for the $21^{\text {st }}$ century in order to have an impact on the wellbeing and fulfillment of today's students and future generations. According to the International Bureau of Education (IBE) document, the curriculum needs to be reconceptualized as follows (Marope, Griffin, \& Gallagher, 2017).

1. The first operational tool for ensuring the sustained development relevance of education and learning systems

2. A catalyst for innovation, disruption, and social transformation

3. A force for social equity, justice, cohesion, stability, and peace

4. An integrative core of education systems

5. An enabler of lifelong learning

6. A determinant of the quality of education and learning

7. A determinant of key cost drivers of education and learning system

8. A lifelong learning system in its own right

SWABK innovation flows along with the future competencies mentioned in IBE document; lifelong learning, self-agency, interactively using diverse tools and resources, interacting with others, interacting with the world, multi-literateness, and trans-disciplinary (Marope \& et al., 2017). Lifelong learners seek new knowledge, explore the unknown and challenging situations, they basically know how to learn. Self-agency is a drive to empower you to figure out the unknown situations and lead to success and fulfilled life. Trans-disciplinary curriculum requires cognitive thinking to integrate knowledge from various disciplines into a new application. Learning should no longer be isolated by subjects.

4.2 The instruction with SWABK innovation would design learning units that provide interactions between 
students and content, peers, teacher, or community anytime anywhere. The instruction should be sensitive to the differences of each student of individual strengths and needs and provide interaction that is prompt and responsive. Variety of learning activities and embedded technology are clearly witnessed. With today's technology, teaching and learning can happen anytime anywhere, the learning can begin even before students enter the classroom. Providing real-time feedback can easily happen. When it comes time to assign work, differentiation can be handled at ease.

4.3 The evaluation with SWABK innovation would provide various types of assessments to serve different learning needs which contain three phases of assessment: for, as, of learning. Schools have been practicing the assessment of knowledge for as long as we could remember. This ineffective assessment must be reformed nimbly because it obstructs cognitive thinking. Assessment needs to inform the learning and should involve students during planning the success criteria and even selecting assessment tasks. Student's self-, or peer assessment during the learning process to improve learning should be conducted. Finally, assessment of learning to showcase performance as a product or result of the learning should be evidenced. All three phases of assessment evolve expected characteristics; seeking challenging situations, welcoming feedback, and criticism, being a cognitive thinker, and knowing what to do when facing uncertain situations.

\section{Conclusion}

The rapid change of the world today has created a question whether what schools teach students today, it would still be useful for students to live successful lives in the future. Also, the rise of international schools in Thailand has generated another question on the effectiveness of the Thai language and culture program in international schools that would definitely affect the lives of Thailand's future leaders. Students who study in international schools are from well to do family judging by the tuition fee. Therefore, it is fair to say they will become our future leaders in economic, political or society. Thai language and culture program has an important role to pave the way for stability for our students in the future, and to serve as a tool to instill characteristics needed to live life successfully in the future. Agile learner characteristics are believed to shape and prepare our students to be ready for the future.

The research findings show that the process of curriculum development needs to identify learning outcomes that align with the need of Thai and global society promoting characteristic of seeking challenging situations, and to design learning units by integrating Thai language and culture into global situations promoting characteristic of being goal-oriented. What students learn is essential to determine how students learn. Thai teachers in international schools need to include not only Thai but global context when developing curriculum. The curriculum needs to be current and relevant to students. Schools that still use Thai subject textbooks as used in Thai school need to urgently consider revising the curriculum. It is not mandatory for international schools to use the text as used in Thai schools as long as schools develop its Thai curriculum following within the OPEC's Thai language and culture curriculum standards. It might seem justified to use the same textbooks as used in Thai subject in Thai schools, Thai national students in international schools could be Thai literate just like Thai students in Thai schools. We could only wish for this thinking to work. Thai class in international schools need to integrate other subjects into it as well. For instance, when learning Thai history, other country's history can be learned by comparing or contrasting and debating good or bad lesson learned from each nation's history. Schools that already use their own developed curriculum should revisit whether it is current to Thai and global society and relevant to students. Performance rubric to assess expected characteristics should be created. Based on the research finding, identifying learning standard basing on proficiency level is currently being handled in the satisfactory level. Stage not age is the key word here. International schools value the differences among students and believe that each and every student is unique in his/her own way. One size does not fit all. With suitable learning activity, students would progress accordingly on his/her proficiency level.

The research findings show that teachers need to construct learning tools and materials to be accessible anytime and anywhere promoting characteristics of being goal-oriented and welcoming feedback and criticism. Learning is unnecessary happening only in the physical classroom with students physically in front of a teacher. Technology can be utilized as a learning and teaching tool that students can interact with the learning at their own pace beyond the classroom setting. Now a day, there are many technological platforms and apps that teachers can use as asynchronous lessons for students to revisit after the physical class for better understand the learned concept or pre-study before coming to the physical class with questions or some background knowledge to further explore collaboratively in the class. The used platform should be interactive that students can either post responses, ideas or ask questions, and generate interactions not only between teacher to students but students to students which provides the opportunity to practice on both feedback giving and receiving. Students should also practice being goal oriented to manage their learning effectively. The autonomy of their learning 
needs to be structured by students in order to reach expected learning goals. Based on the research findings, the following areas are currently being handled in the satisfactory level; identifying learning objectives aligning with learning outcomes, constructing learning activities connecting to the community and engaging learners at each proficiency level, and identifying assessment evidence suitably to each learner differences. These practices align with the best practice under the curriculum development that student's different learning needs are highly valued. Also learning activity connecting to community is commonly witnessed in international schools. Students annually engage in at least one project related to the community such as fundraising for orphanages, for smile operation, or for book donation to local Thai schools. Students learn to be caring citizens of the community they live in.

The research findings show that teachers need to utilize the evaluation result to further develop learners to be ready for the future promoting the characteristic of being goal-oriented. Teachers need to examine starting from the curriculum, instruction and evaluation whether it is future-ready and serves student's different learning needs. Assessment should occur before, during and after the learning. Especially during the learning is frequent in nature to inform where students are at so that teachers can adjust learning activity to meet the student's needs. Students also need to set their learning goals for each class. Self- and peer assessment should be common practices during the learning to see whether the set goal has been met or areas needed improvement. At the completion of learning, student's knowledge should be assessed as how students apply the learned knowledge into creation for an artefact. Based on the research findings, the following areas are currently being handled in the satisfactory level; examining learner's quality according to indicated learning outcomes, examining curriculum's suitability to Thai and global societies, and examining the instructions reflection on differences of each learner. This reflects the management cycle that there is an assessment at the end in each element starting from the quality of learners that need to be aligned with the outcomes, the suitability of what students learn, any adjustment needed, and student's engagement suitable for each student's learning needs.

\section{References}

Admin. (2019). Update tuition fee of 24 international schools in Thailand for 2019-2020 school year. Retrieved from https://campus.campus-star.com/education/54725.html

Anderson, J. (2017). The Agile Learner. Australia: Hawker Brownlow Education.

Bangkok, I. S. (2016). ISB Profile. Retrieved from https://www.isb.ac.th/images/2016/10/ISB_Profile_2016-2017.pdf

Board, O. o. t. N. E. a. S. D. (2018). National Strategy 2018-2037 (Summary). Bangkok: National Strategy Secretariat Office Retrieved from http://nscr.nesdb.go.th/wp-content/uploads/2019/04/NS_Eng_A5.pdf

Burke, W., Roloff, K., \& Mitchinson, A. (2016). Learning agility: A new model and measure (Working Paper).

CIS. International Accreditation. Retrieved from https://www.cois.org/for-schools/international-accreditation

De Meuse, K. P., Dai, G., \& Hallenbeck, G. S. (2010). Learning agility: A construct whose time has come. Consulting Psychology Journal: Practice and Research, 62(2), 119. https://doi.org/10.1037/a0019988

Doyle, A. (2019). Top 10 Leadership Skills: Leadership Skills Employers Look For. Retrieved from https://www.thebalancecareers.com/top-leadership-skills-2063782

EDT. International Schools Quality Mark. Retrieved from https://www.educationdevelopmenttrust.com/search

Education, T. S. o. t. C. o. (2017). National Education Plan 2017-2036. The Secretariat of the Council of Education. Retrieved from http://www.lampang.go.th/public60/EducationPlan2.pdf

Galagan, P. (2015). The Quest for the Agile Learner. TD Magazine. Retrieved from https://www.td.org/magazines/td-magazine/the-quest-for-the-agile-learner

GROUP, L. M. Innovation: It doesn't have to be so hard. Retrieved from https://www.leanmethods.com/resources/articles/innovation-it-doesnt-have-be-so-hard/

Hallenbeck, G., Swisher, V., \& Orr, J. E. (2011). Seven faces of learning agility-Smarter ways to define, deploy, and develop high-potential talent. Korn Ferry Institute. Retrieved from http://www.kornferry.com/media/lominger_pdf/Seven_faces_of_learning_agility.pdf

Hattori, S. (2015). The McKinsey Edge: Success Principles from the World's Most Powerful Consulting Firm: McGraw Hill Professional.

Hengsberger, A. (2018). The 4 phases of innovation. Retrieved from https://www.lead-innovation.com/english-blog/the-4-phases-of-innovation 
Howells, K. (2018). The future of education and skills: Education 2030: The future we want.

Kinahan, D. (2017). How well do schools prepare children for their future? Retrieved from http://www.educationappg.org.uk/wp-content/uploads/2017/04/Preparing-for-the-future-inquiry-report.pdf

Lewis, J., Orr, J., \& Buxton, C. (2014). CEO Insights: female entrepreneurial talent. Retrieved from https://www.kornferry.com/institute/ceo-insights-can-organizations-gain-edge-tapping-female-entrepreneuri al-talent

Lombardo, M. M., \& Eichinger, R. W. (2000). High potentials as high learners. Human Resource Management, 39(4), 321-329. https://doi.org/10.1002/1099-050X(200024)39:4<321::AID-HRM4>3.0.CO;2-1

Marope, M., Griffin, P., \& Gallagher, C. (2017). Future Competences and the Future of Curriculum. Retrieved from http://www.ibe.unesco.org/en/news/document-future-competences-and-future-curriculum

Mitchinson, A., \& Morris, R. (2012). Learning about learning agility. A White Paper. https://doi.org/10.5465/AMBPP.2012.288

MoE. (2007). Standard Indicators for International Schools. Retrieved from https://www.rsu.ac.th/legal/File/B/5.pdf

NEASC. Foundation Standards. Retrieved from https://www.neasc.org/

Ng, S. (2014). The innovaiton process for Development Innovations Orientation. Retrieved from https://www.s lideshare.net/Oung_Samnang/the-innovation-process-for-development-innovations-orientation

O'Sullivan, D., \& Dooley, L. (2009). Applying Innovation. Thousand Oaks: SAGE Publications, Inc.

OPEC. (2016). Thai Language, Culture and History for International Schools. 99. Retrieved from https://www.opec.go.th/ckfinder/userfiles/files/KN/Education\%20Quality\%20Dev/Ex.International\%20sch ool/Thai\%20and\%20Thai\%20Culture.pdf

School, B. P. (2020). Policies and Placement. Retrieved from https://www.patana.ac.th/admissions/policies-and-placement/

School, N. I. (2020). Diverse \& International. Retrieved from https://www.nist.ac.th/community/

Somboon, U. (2017). International School 4.0. Paper presented at the ISAT: International School 4.0.

Spurgin, S. (2016). Are you an agile learner? Retrieved from https://www.linkedin.com/pulse/you-agile-learner-sean-spurgin/

Torii, K., \& O'Connell, M. (2017). Preparing young people for the future of work: Policy roundtable report.

Valcour, M. (2015). 4 Ways to Become a Better Learner. Retrieved from https://hbr.org/2015/12/4-ways-to-become-a-better-learner

WASC, A. (2016). International Schools. Retrieved from https://www.acswasc.org/schools/international/

\section{Copyrights}

Copyright for this article is retained by the author(s), with first publication rights granted to the journal.

This is an open-access article distributed under the terms and conditions of the Creative Commons Attribution license (http://creativecommons.org/licenses/by/4.0/). 